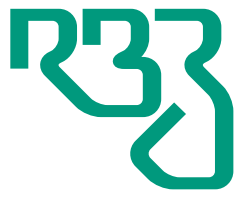

Revista

Brasileira de

Zootecnia

Brazilian Journal of Animal Science

ISSN 1806-9290

www.rbz.org.br

\section{Overprice on purchase of replacement cattle and genetic group as variables of economic result in feedlot operations}

\author{
Kárito Augusto Pereira $^{1}$ (iD), Fernando de Paula Leonel ${ }^{1,2^{*}}$ (iD), Janderson

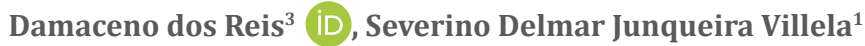 \\ ${ }^{1}$ Universidade Federal dos Vales do Jequitinhonha e Mucuri, Programa de Pós-Graduação \\ em Zootecnia, Diamantina, MG, Brasil. \\ ${ }^{2}$ Universidade Federal de São João del-Rei, Departamento de Zootecnia, São João del-Rei, \\ MG, Brasil. \\ ${ }^{3}$ Universidade Federal de Viçosa, Departamento de Economia Rural, Viçosa, MG, Brasil.
}

*Corresponding author: fernandoleonel@ufsj.edu.br

Received: August 4, 2018

Accepted: June 14, 2019

How to cite: Pereira, K. A.; Leonel, F. P.; Reis, J. D. and Villela, S. D. J. 2019. Overprice on purchase of replacement cattle and genetic group as variables of economic result in feedlot operations. Revista Brasileira de Zootecnia 48:e20180186

https://doi.org/10.1590/rbz4820180186

Copyright: This is an open access article distributed under the terms of the

Creative Commons Attribution License (http://creativecommons.org/licenses/by/4.0/), which permits unrestricted use, distribution, and reproduction in any medium, provided the original work is properly cited.

\begin{abstract}
The objective of this study was to analyze the economic result of feedlot operation for three genetic groups of cattle (Nellore, Nellore crossing with other Zebuine breeds, and Dairy crossbred) as a function of the overprice on the purchase price of cattle to be feedlot-finished. The study involved data of 57,589 animals divided into 709 lots originating from operation cycles from March to December 2016. Lots were considered replicates, and gross margin per animal was considered the economic result. Data pertaining to each lot, overprice, and gross margin were analyzed by regression, with mathematical models developed for each genetic group. After significance tests were applied, simple linear models were adopted for all studied groups. To check the equality or lack thereof of the three regression models generated, we used a modelidentity test, which revealed that the model for Nellore animals was different from that used for Dairy crossbreds. The model generated for Nellore crossing with other Zebuine breeds did not differ from the models for Nellore or Dairy crossbreds, i.e., Nellore crossing with other Zebuine breeds may be grouped as a single model together with the Nellore group or with the Dairy-crossbred group. The estimates generated from the three individualized models suggest that the purchase of the feeder (unfinished) cattle for the Dairy crossbred, Nellore crossing with other Zebuine breeds, and Nellore groups, with an overprice starting at $1.19,1.21$, and 1.27 , respectively, will result in negative gross margins. Thus, the overprice at purchase may compromise the economic result of feedlot operation, and more-efficient animals may allow for a greater overprice on the purchase in the operation, with a positive gross margin.
\end{abstract}

Keywords: dairy crossbred, gross margin, Nellore, Nellore crossbred

\title{
Introduction
}

Feedlot operations in Brazil has no longer been a merely exploratory management option during the offseason of livestock. This strategy is now an important part of every production chain as a result of the growing demand for the meat commodity over the years. However, uncertainties regarding the activity during production and sale expose the agents of the chain to risks that may compromise the results of the activity.

In recent years, the overprice between the purchase cost of the arroba (@=15 kg) of feeder (unfinished) cattle and the sale price of the arroba of fat (finished) cattle, coupled with elevated production costs, has led to some of the lowest fat cattle/feeder cattle exchange rates in history. This has caused the 
producer to retain animals for a longer period in the feedlot in an attempt to minimize the expenditure on the purchase of replacement animals and, thus, add more weight to those already confined.

Because the feedlot farmer is not able to interfere with the sale price of the finished cattle, the only way of obtaining gains is to know the production costs and their components to reduce them (Correa et al., 2014). Thus, the decision-making process regarding animal purchase price, which accounts for the largest share of disbursement in a feedlot system, may be paramount for a profit or loss from this operation.

The manager of an operation of narrow margins, as is the case of feedlot operations, is constantly involved in decisions that will influence the result of the activity. The difference in performance of each genetic group (breeds and crossbreeds), which at times implies variations in the purchase price of the feeder cattle, is another variable to be considered at the time of the purchase of animals to enter the system. However, special attention should be directed towards defining to which point an overprice can be paid due to the different genetic options available.

In this scenario, the great challenge in management is to find a price range for the purchase of feeder cattle for the different genetic groups, which, associated with a performance estimation during the feedlot period, will provide economic viability to the activity.

The objective of this study was to identify the overprice range in the purchase of the arroba of feeder cattle relative to the sale price of fat cattle, in three genetic groups.

\section{Material and Methods}

The data used in this study originated from a farm located in Barretos, SP, Brazil, with static capacity for 17,000 animals and appropriate facilities for the development of beef cattle feedlot operation.

Data of male animals from three genetic groups [Nellore, Nellore crossbred (Nellore $\times$ another zebuine breed - subspecies Bos taurus indicus), and Dairy crossbred (Holstein $\times$ Gir)] were collected. These data were generated in different finishing cycles in the period from March 2014 to December 2016 that totaled 57,589 animals distributed into 709 lots. Each lot (with approximately 70-90 animals) was adopted as a replicate. For standardization, these 709 lots (animals 57,589) were drawn from a total of 1178 lots (96,542 animals). To compose the three genetic groups, lots of animals were chosen, in each finishing cycle, with the best possible approximation for input entry weights in the feedlot, slaughter weight, and feeding days. However, it is noted that these variables are influenced by breeds and crosses. Thus, a forced numerical approximation for them can result in changes in the peculiarities of one of the factors under study (breed/crosses). The entry weights in the feedlot, slaughter weight, and feeding days were respectively $390 \mathrm{~kg}, 560 \mathrm{~kg}$, and 113 days. These variables were obtained from the averages of all the animals used in the study, i.e., from the three genetic groups.

In the formulation of the purchase price of the arroba of feeder cattle (animal entering the feedlotfinishing system), we considered a carcass dressing percentage (DP) of 50\%, i.e., Weight in @ $=\frac{B W_{L} \times 0.5}{15}$, in which $\mathrm{BW}_{\mathrm{L}}=$ body weight of the live animal. For the fat cattle, we considered the actual DP of each animal obtained at the meat-packing plant (Table 1).

Table 1 - Means \pm standard deviations for slaughter weight and dressing percentage of feedlot cattle according to genetic breed during the analyzed period

\begin{tabular}{lcc}
\hline Genetic group & Slaughter weight $(\mathrm{kg})$ & Dressing percentage \\
\hline Nellore & $565.07 \pm 50.77$ & $57.00 \pm 0.02$ \\
Nellore crossing with other Zebuine breeds & $567.21 \pm 50.82$ & $56.26 \pm 0.02$ \\
Dairy crossbred & $537.90 \pm 50.95$ & $54.79 \pm 0.02$ \\
\hline
\end{tabular}


The actual operating cost of the arroba produced $\left(A O C @_{\mathrm{p}}\right.$ ) was considered to be the disbursement made by the producer to finance the activity during the period. This variable was calculated by the following equation:

$$
A O C @_{P}=\frac{\left(D M I_{D} \times D C_{D M} \times D F\right)+M C}{N @_{F P}},
$$

in which $\mathrm{DMI}_{\mathrm{D}}=$ daily dry matter intake; $\mathrm{DC}_{\mathrm{DM}}=$ daily cost of dry matter; $\mathrm{DF}=$ days in the feedlot; $\mathrm{MC}=$ miscellaneous costs (labor, electrical energy, loading and unloading of feed, vaccines, and medication), which were considered $10 \%$ of the total feed cost; and $\mathrm{N} @_{\mathrm{FP}}=$ number of arrobas produced during the feedlot period.

The economic result was assessed as a function of the gross margin (GM) of the activity and of the overprice on the purchase of feeder cattle, determined as the ratio between the purchase price of the arroba of feeder cattle and the sale price of the arroba of fat cattle. Gross margin was calculated as $\mathrm{GM}=\mathrm{RFC}-\mathrm{AOC}$, in which RFC = revenue from the sale of fat cattle and AOC = actual operating cost per animal. The overprice was obtained as $\frac{P P @}{S P @}$, in which PP@ = purchase price of the arroba of feeder cattle and SP@= sale price of the arroba of fat cattle.

To determine whether there were differences for the actual operating cost of the arroba produced between the three genetic groups studied, the data were subjected to an analysis of variance, and because it was significant at 5\%, means were compared by the SNK (Student-Newman-Keuls) test also at the $5 \%$ probability level.

To evaluate the economic result, linear regression equations were adjusted for GM per lot as a function of the overprice on the purchase of arroba. To check possible differences of this economic result between the genetic groups under study [dairy crossbred (DC), Nellore (N), and Nellore crossbred (NC)], the model-identity test suggested by Graybill (1976) was performed.

The test was executed as follows: first, a regression equation was fitted using the complete set of data from the three genetic groups and, by the analysis of variance of the regression, we obtained the residual sum of squares $\left(R S S_{D C, N, N C}\right)$. The same procedure was adopted using combinations of only two genetic groups to obtain the residual sum of squares originating from the fitting of the linear regression to the combined data of dairy crossbred with Nellore $\left(R S S_{D C, N}\right)$, dairy crossbred with Nellore crossbred $\left(R S S_{D C, N C}\right)$, and Nellore with Nellore crossbred $\left(R S S_{N, N C}\right)$. Later, linear regression equations were fitted with the data of each genetic group individually to obtain the residual sum of squares for dairy crossbred $\left(R S S_{D C}\right)$, Nellore $\left(R S S_{N}\right)$, and Nellore crossbred $\left(R S S_{N C}\right)$. The residual sums of squares $\left(R S S_{i}\right)$ obtained in each fitting were used to calculate the following differences $\left(D_{i}\right)$ :

$$
\begin{gathered}
D_{1}=R S S_{D C, N, N C}-\left(R S S_{D C}+R S S_{N}+R S S_{N C}\right) \\
D_{2}=R S S_{D C, N}-\left(R S S_{D C}+R S S_{N}\right) \\
D_{3}=R S S_{D C, N C}-\left(R S S_{D C}+R S S_{N C}\right) \\
D_{4}=R S S_{N, N C}-\left(R S S_{N}+R S S_{N C}\right)
\end{gathered}
$$

Based on the $D_{i}, R S S_{i}$, number of observations of each genetic group ( $n_{D C}=$ dairy crossbred; $n_{N}=$ Nellore; and $n_{N C}=$ Nellore crossbred), and number of parameters of each regression $(p)$ - which, in the case of linear regression, are two $\beta_{0}$ and $\beta_{1}-$, four $F_{i}$ statistics were calculated:

$$
F_{1}=\frac{D_{1} / p}{\left(R S S_{D C}+R S S_{N}+R S S_{N C}\right) /\left(n_{D C}+n_{N}+n_{N C}-3 p\right)}
$$




$$
\begin{aligned}
& F_{2}=\frac{D_{2} / p}{\left(R S S_{D C}+R S S_{N}\right) /\left(n_{D C}+n_{N C}-2 p\right)} \\
& F_{3}=\frac{D_{3} / p}{\left(R S S_{D C}+R S S_{N C}\right) /\left(n_{D C}+n_{N C}-2 p\right)} \\
& F_{4}=\frac{D_{4} / p}{\left(R S S_{N}+R S S_{N C}\right) /\left(n_{N}+n_{N C}-2 p\right)}
\end{aligned}
$$

The $F_{i}$ statistics were compared with tabulated $F$ at the $\alpha=0.05$ level to test the following hypotheses:

$\mathrm{H}_{0}$ : the regression equation parameters are equal for all genetic groups;

$\mathrm{H}_{0}$ : the regression equation parameters are equal for dairy crossbreds and Nellore;

$\mathrm{H}_{0}$ : the regression equation parameters are equal for dairy crossbreds and Nellore crossbreds; and

$\mathrm{H}_{0}$ : the regression equation parameters are equal for Nellore and Nellore crossbreds.

The $\mathrm{H}_{0}$ hypotheses were rejected in cases where $F_{i}>$ tabulated $F$.

\section{Results}

Differences were detected $(\mathrm{P}<0.05)$ for AOC@ ${ }_{\mathrm{P}}$ between the three genetic groups (Figure 1$)$. The cost for the production of $1 @$ for the dairy crossbreds was higher $(\mathrm{P}<0.05)$ than that of Nellore crossbreds, which in turn was higher $(\mathrm{P}<0.05)$ than the cost per arroba of Nellore animals.

The analyses of identity of the regression model parameters revealed that the model generated for the Nellore animals $\left(\overline{G M_{\text {Animal }}}\right)=2081.6+\left(-1641.4 \times \frac{P P @}{S P @}\right) ; R^{2}=0.86$, in which $\mathrm{GM}=$ gross margin per animal in the feedlot; PP@ = purchase price of the arroba of cattle entering the feedlot; and SP@ = sale price of the arroba of fat cattle) differed $(\mathrm{P}<0.05)$ from the model generated for the dairy crossbred $\left.\left(\overline{G M_{\text {Animal }}}\right)=2101.7+\left(-1773.1 \times \frac{P P @}{S P @}\right) ; R^{2}=0.84\right)$. However, the model generated for the animals from the Nellore-crossbred group $\left.\left(\overline{G M_{\text {Animal }}}\right)=2146.3+\left(-1782.3 \times \frac{P P @}{S P @}\right) ; R^{2}=0.89\right)$ did not differ $(\mathrm{P}>0.05)$ from that obtained for the Nellore animals or dairy crossbreds. In other words, for this group (Nellore crossbreds), GM as a function of the ratio between purchase price of the arroba of feeder cattle and sale price of the arroba of fat cattle can be estimated using any of the three models.

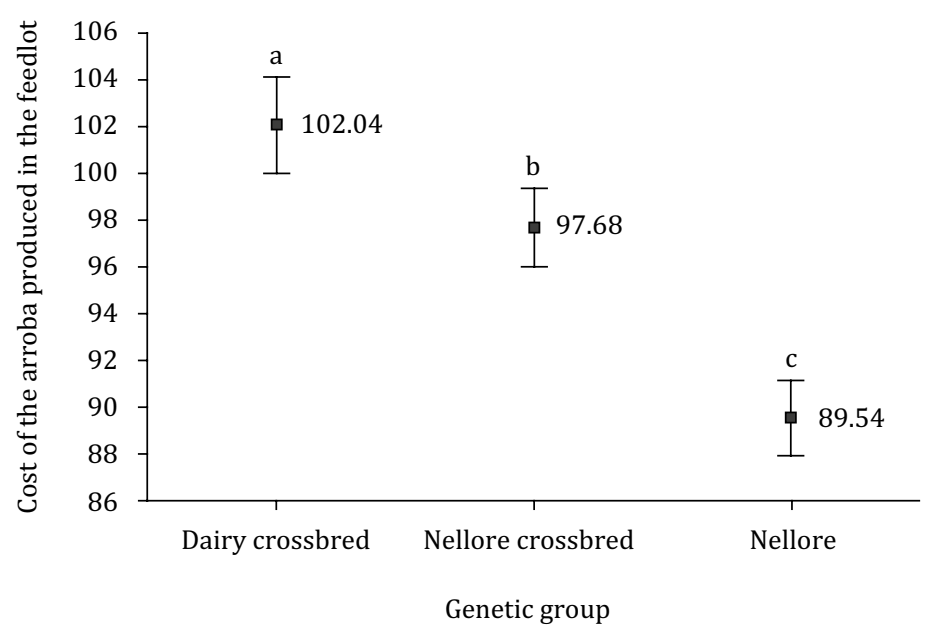

Figure 1 - Actual operating cost of the arroba produced between the three genetic groups. 
With the model generated for the Nellore animals (Figure 2A), it can be estimated that an overprice paid for the arroba of feeder cattle of up to 1.27 (SP@=27\% > PP@) will result in a positive GM. In this case, the activity is paying off and shall persist at least in the short term. From that point (1.27), it will result in a negative GM. Of the 286 lots of Nellore animals evaluated here, $86.71 \%$ had a positive GM, with an average of BRL 311.52 per animal, corresponding to 2.08 @ in the sale price.

With the same analysis for the dairy crossbred, it can be inferred, based on the PP@:SP@ ratio of 1.19 (Figure 2B) that the GM becomes negative. Of the 166 lots evaluated, $76.51 \%$ showed a positive GM per animal. For this group, the average GM was BRL 257.61 per animal, corresponding to 1.72 @ in the sale price.

For the Nellore crossbred, GM remained positive up to 1.21 (Figure 2C). Of the 257 lots evaluated, $75.10 \%$ showed a positive GM per animal, with an average of BRL 254.09, corresponding to 1.69 @ in the sale price.

Therefore, the third and fourth hypotheses of $\mathrm{H}_{0}$ prevailed in the curves generated from the regression models of the three genetic groups studied here, suggesting that the same linear regression model can be used to estimate the overprice of genetic groups composed of dairy crossbred and Nellore crossbred. However, an independent model must be used exclusively for the Nellore group (Figure 2D).

\section{Discussion}

The lower AOC@ $@_{\mathrm{p}}$ of Nellore animals can be explained by the variation in conversion efficiency of feed into body mass among the animals of these three genetic groups, in which case the Nellore has

A

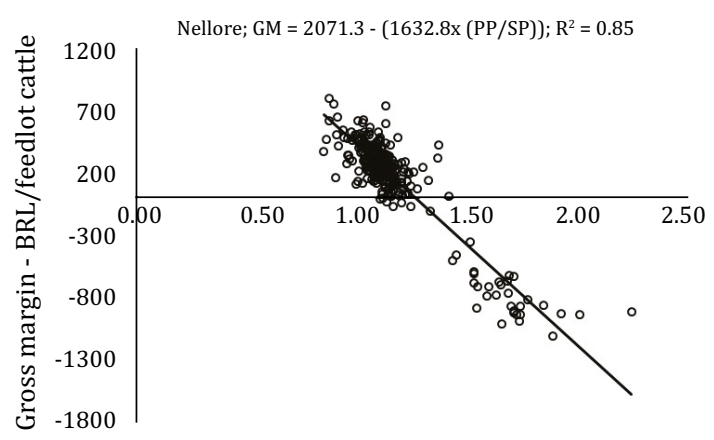

Purchase price of the arroba of feeder cattle/ sale price of the arroba of fat cattle

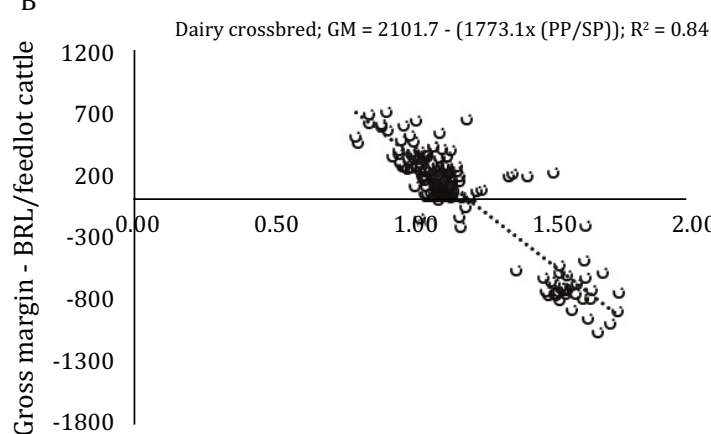

Purchase price of the arroba of feeder cattle/ sale price of the arroba of fat cattle

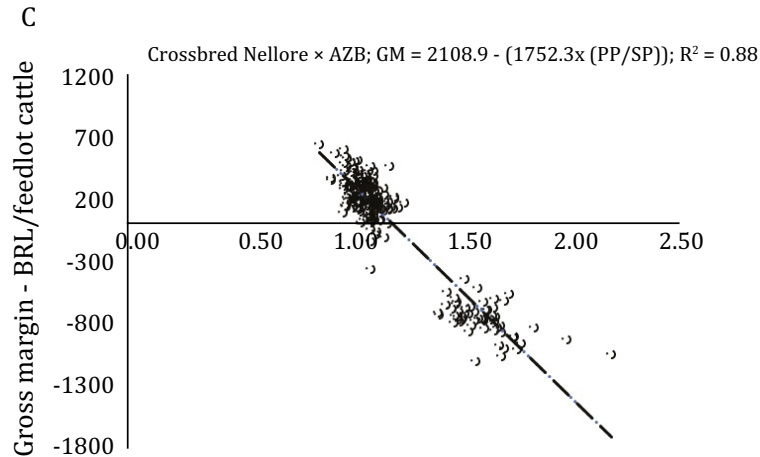

Purchase price of the arroba of feeder cattle/ sale price of the arroba of fat cattle

D

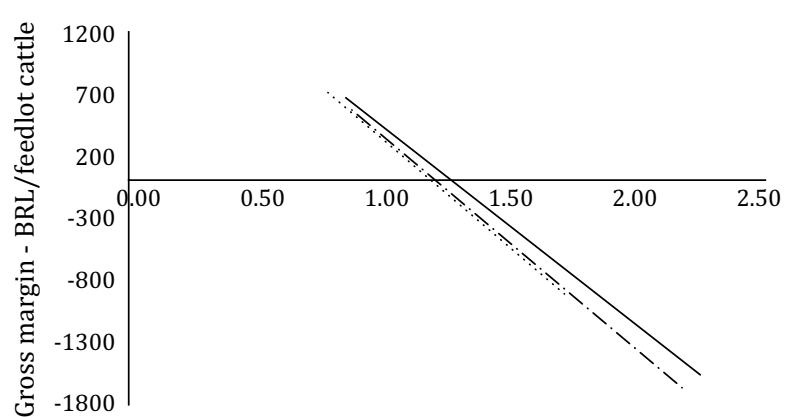

Purchase price of the arroba of feeder cattle/ sale price of the arroba of fat cattle

.... GM DC _ GM Nellore -.. GM N×AZB

GM Nellore: gross margin of the Nellore; GM N×AZB: gross margin of the Nellore crossing with other Zebuine breeds; GM DC: gross margin of the dairy crossbred.

Figure 2 - Gross margin per feedlot cattle as a function of the ratio between the purchase price of the arroba of feeder cattle and the sale price of the arroba of fat cattle. 
superior performance. Fernandes et al. (2004) found a higher feed efficiency in Nellore animals than in dairy breeds.

Performance during the feedlot stage is one of the factors determining the GM per animal. The present results indicate that the animals with better performance - the Nellore, in this study - allow for a higher overprice on the purchase of feeder cattle. In this case, these limits, represented by an overprice paid for the arroba of feeder cattle of up to 1.19, 1.21, and 1.27 for the dairy crossbred, Nellore crossbred, and Nellore, respectively, resulted in a positive GM.

The greater performance in the feedlot can dilute the costs in this stage of the activity and even contribute to covering the overprice on the purchase of feeder cattle (Damato and Yotsuyanagi, 2015).

Therefore, one can invest a little more in the purchase of more specialized animals for feedlot finishing than of less specialized animals, under the prospect of a positive economic outcome. However, for each scenario, there will be a limit for this surplus value so that no negative margin is incurred.

Christofari et al. (2009) stressed that the marketing of the arroba purchase:sale price ratio (overprice) is an economically essential aspect, since an inefficient purchase or sale may compromise the entire endeavor put forward during the development of the activity. This elucidates the representativeness of the genetic factor to the overprice on the purchase in the cattle-finishing operation.

Many researchers (Demeu et al., 2012; Demeu et al., 2013; Lopes et al., 2013; Mandarino et al., 2013; Geron et al., 2014; Raupp and Fuganti, 2014) have shown the influence of the purchase price of animals on the economic return of the finishing process. This item accounts for $70 \%$ of the total costs of the operation, i.e., knowing this exchange rate (sale price of the arroba of fat cattle/purchase price of the arroba of the cattle to be feedlot-finished) is fundamental in the predictability and decision-making for the finishing operation (Machado and Berger, 2012).

The period when the data were generated (confinement cycles from 2014 to 2016) presented an elevated demand for feeder cattle and the lowest recorded fat cattle/feeder cattle exchange rate in the history of prices. Many are the factors that contributed to this scenario, though a noteworthy trend exists towards increased static capacity of the main feedlots.

Such growth in the feedlot structure has been leveraged through an increase in grain-production technology that resulted in attractive prices of these inputs and their byproducts; adoption of high-energy diets with the mastership of practices for enabling this type of diet; and optimization of the implemented structure and trained hired labor. These factors go along with the search for an increased scale of purchase of inputs and sale of finished animals, which provides comparative advantages per unit of sold product. However, in 2016, there was a substantial rise in the price of corn, one of the main inputs used in the feedlot operation.

In a setting of intensifying overprice for the arroba of cattle to be feedlot-finished, the purchase of lighter animals may be an important alternative, since the purchase cost is determined based on the weight of live animal. In this way, two important variables help in the possible generation of a positive economic output: overprice on a lower number of arrobas purchased, which results in a dilution of the surplus value to be offset through weight gain during the feedlot stage; and use of the animal in a stage of the growth curve favorable to muscle-tissue deposition, which makes weight gain more efficient as a result of a better feed conversion.

\section{Conclusions}

The cost per produced arroba of Nellore animals during the feedlot period is lower than that of Nellore crossing with other Zebuine breeds and dairy crossbred. Data of Nellore and dairy crossbred animals should not be grouped in the same model to estimate gross margin as a function of the overprice on the purchase. Irrespective of breed, the overprice on the purchase of feeder cattle should be a target variable; in this regard, more-efficient animals allow for a higher overprice on the purchased arroba. 


\section{Conflict of Interest}

The authors declare no conflict of interest.

\section{Author Contributions}

Conceptualization: K.A. Pereira, F.P. Leonel, J.D. Reis and S.D.J. Villela. Formal analysis: J.D. Reis and S.D.J. Villela. Investigation: K.A. Pereira and F.P. Leonel.

\section{Acknowledgments}

The authors thank the Coordenação de Aperfeiçoamento de Pessoal de Nível Superior (CAPES) for the scholarship granted; Confinamento Monte Alegre (CMA), for providing the experimental data; and Douglas Sampaio Henrique (in memoriam), for quantitative analysis.

\section{References}

Christofari, L. F.; Barcellos, J. O. J.; Braccini Neto, J.; Oaigen, R. P.; Canozzi, M. E. A. and Wilbert, C. A. 2009. Manejo da comercialização em leilões e seus efeitos no preço de bezerros de corte. Revista Brasileira de Zootecnia 38:196-203. https://doi.org/10.1590/S1516-35982009000100024

Correa, A. C. M.; Leão, I. A.; Araújo, L. T.; Soares, L. A. and Souza, W. A. 2014. Avaliação dos preços do boi gordo no Estado de Goiás: Análise da trajetória de 2008 a 2012. Revista em Agronegócios e Meio Ambiente 7:613-632.

Damato, S. B. and Yotsuyanagi, S. E. 2015. A importância do planejamento estratégico associado à utilização de ferramentas de controle para maximização da lucratividade em confinamento de gado de corte. Revista iPecege 1:59-78. https://doi.org/10.22167/r.ipecege.2015.2.59

Demeu, A. A.; Lopes, M. A. and Barbosa, F. A. 2012. Resultados econômicos da terminação de bovinos de corte em confinamento no município de Sete Lagoas - MG. Boletim de Indústria Animal 69:13-22.

Demeu, A. A.; Lopes, M. A.; Barbosa, F. A.; Ribeiro, A. D. B. and Carvalho, F. M. 2013. Efeito da escala de produção na rentabilidade de bovinos de corte em regime de pastejo no Sul de Minas Gerais. Archivos Latinoamericanos de Producción Animal 21:97-106.

Fernandes, H. J.; Paulino, M. F.; Martins, R. G. R.; Valadares Filho, S. C.; Torres, R. A.; Paiva, L. M. and Moraes, G. F. B. K. 2004. Ganho de peso, conversão alimentar, ingestão diária de nutrientes e digestibilidade de garrotes não-castrados de três grupos genéticos em recria e terminação. Revista Brasileira de Zootecnia 33:2403-2411. https://doi.org/10.1590/S1516-35982004000900029

Geron, L. J. V.; Moura, D. C.; Rodrigues, D. N.; Paula, E. J. H.; Trautmann-Machado, R. J.; Garcia, J.; Schumann, A. M. and Silva, D. A. 2014. Viabilidade econômica de tourinhos terminados em confinamento alimentados com diferentes teores de caroço de algodão em dietas elaboradas com co-produtos agroindustriais. Semina: Ciências Agrárias 35:2673-2684.

Graybill, F. A. 1976. Theory and application of the linear model. Duxburg Press, Massachussetts.

Lopes, M. A.; Ribeiro, A. D. B.; Nogueira, T. M.; Demeu, A. A. and Barbosa, F. A. 2013. Análise econômica da terminação de bovinos de corte em confinamentos no estado de Minas Gerais: estudo de caso. Revista Ceres 60:465-473. https://doi.org/10.1590/S0034-737X2013000400004

Machado, C. F. and Berger, H. 2012. Uso de modelos de simulación para asistir decisiones en sistemas de producción de carne. Revista Argentina de Producción Animal 32:87-105.

Mandarino, R. A.; Barbosa, F. A.; Cabral Filho, S. L. S.; Lobo, C. F.; Silva, I. S.; Oliveira, R. V.; Diogo, J. M. S. and Guimarães Júnior, R. 2013. Desempenho produtivo e econômico do confinamento de bovinos zebuínos alimentados com três dietas de alto concentrado. Arquivo Brasileiro de Medicina Veterinária e Zootecnia 65:1463-1471. https://doi.org/10.1590/S0102-09352013000500027

Raupp, F. M. and Fuganti, E. N. 2014. Gerenciamento de custos na pecuária de corte: um comparativo entre a engorda de bovinos em pastagens e em confinamento. Custos e Agronegócio Online 10:282-316. 